\title{
Bits of Autobiography: Radical Deindividualization and Everydayness
}

\begin{abstract}
TN A typically biting i 897 essay titled "The Short Story," Ambrose Bierce critiques William Dean Howells, at the time the reigning practitioner of realism and America's foremost critic of literature. Bierce calls attention to the lack of any structuring events and the paucity of representations of the exceptional, or of what he terms "imagination," in Howells's championed mode of realism. Howells, Bierce claims, can only produce art from what he has directly experienced and that, unfortunately, has been strictly limited to the banal worries and anxieties of the class of Americans to which he belongs. Howells's friends and acquaintances do not, according to Bierce, constitute a subject worthy of literature. He writes:
\end{abstract}

The magazine story must relate nothing: like Dr. Hern's "holes" in the luminiferous ether, it is something in which nothing can occur. ... The master of this detestable school of literature is Mr. Howells. Absolutely destitute of that supreme and sufficient literary endowment, imagination, he does, not what he would, but what he can-takes note with his eyes and ears and "writes them up" as does any other reporter. He can tell nothing that he has not seen or heard, and in his personal progress through the rectangular streets and between the trim hedges of Philistia, with the lettered old maids of his acquaintance curtseying from the door-ways, he has seen and heard nothing worth telling. Yet tell it he must, and having told, defend. (243) 
Representations of particularity, exceptional and individualizing moments, thus form the missing elements that, for Bierce, mark the difference between serious literature and the middlebrow realistic fiction promoted by the school of Howells. For something rather than "nothing" to occur, Bierce argues that literature must give up the perspective associated with the journalistic gaze constructed through the figure of the author-as-narrator.

In effect Bierce here defends his own mode of writing, which might be more closely identified with the literary mode of romance, against this form of realistic representation on the grounds of his application of the imagination to what he terms the "impenetrable motives" of men and women. Bierce believes that only by escaping the bounds of generic experience, which he understood as necessarily limited, can one create a story "worth telling," and more, worth reading. More specifically, Bierce worries that the mode of realism he finds in Howells attempts to turn what, for him, amounted to his most horrific discovery-that one can be made into or make oneself a generic person-into the basis for the literary representation of life. What could seem comforting to someone like Howells appears for Bierce a fate worse than death. He believes that to represent a subject in general terms means inflicting a radical loss of individuality on that subject, for it means imagining that subject as anyone or no one in particular. In his critique of Howells, Bierce links the generic generality of Howellsian realism to what he sees as the anonymous common story. When used in autobiography that common story becomes masochistic, a form of deindividualizing violence directed toward the self.

Bierce's disagreement with Howells concerns a shift in the understanding of everydayness or common, shared identity. Nineteenth-century realism was invested in the representation of the common. In order to represent the world as it really was, in other words to make a claim on reality, authors working within this tradition needed to carefully manage the creation of commonness. One way in which these authors, and Howells in particular, produced the effect of realism was to include the representation of an anomalous figure that could then be excluded from the field of the common. ${ }^{1}$ In the later years of the nineteenth century, such aesthetics were no longer capable of producing a sense of comfort. Once faith in shared identity is lost, the deindividuation that has been understood to be required by literary realism becomes an obsessive concern. 
Bierce's own literary work is interested in the phenomenology of his particularity of experience, even at the cost of admitting the insignificance of this experience. The events selected by Bierce for textual representation are partial, personal, and punctual, qualities evident both in the title of his autobiographical collection, Bits of Autobiography, and in many of the eleven "bits" selected for this collection: "A Little of Chickamauga," "What I Saw of Shiloh," "Four Days in Dixie," and "A Sole Survivor." These titles all suggest Bierce's partial, even narrow, scope. From the limited period of "four days" to the extent of what was visible in "what I saw," these titles do not solidify experience into authoritative narrative; they are bits of experience that have broken off, or have been broken off, from some potentially more meaningful larger story. While seven of his eleven narrative bits cover his experiences during the war, he frames the collection with, at one end, his 1861 initiation into battle. The concluding bit is a lonely and melancholic meditation on outliving all his friends and peers as a single, solitary remainder of the past.

Unlike Henry Adams or Henry James, two of the major autobiographers of the period, Bierce's short autobiographical bits do not make any explicit attempt to connect his personal history to that of the nation. This is so even though his narrative life begins not with his birth in 1842 but twenty-one years later, in the summer of $\mathrm{I} 86 \mathrm{I}$, when he left home to join the Ninth Indiana Volunteers. His limited scope, in terms of both form and the content, restricts the applicability of any insights gained to larger interpretive frameworks. We should, of course, have doubts that Bierce would have ever written a large and "complete" autobiography like that of Ulysses S. Grant, whose bestselling The Personal Memoirs of Ulysses S. Grant (I885) was perhaps one of the few autobiographies of the period that stuck close to genre conventions and the long form. Bierce was, after all, a relentless critic of the novel form and what he saw as its unnecessary and distracting length. When, to take one telling example, he narrates his experiences during the battle at Chickamauga, we do not find any resolution capable of producing a tight linkage to the meaning of the Civil War as a whole; there is an active destruction, a deferral of larger meaning in his texts. Not unlike the "private histories" found in several stories and sketches written by Mark Twain, Bierce's narrative never rises out of his personal experiences within the fog of war. The same applies to his representation of 
the Civil War in general.

In Bierce's own work, both the "bit" and the "common story" that he critiques in Howells serve similarly to deindividuate individuals. The anomalous story, either that of a bit that was once whole, and thus no longer an individual, or a hypersubjective personality that cannot integrate bits of experience into a larger meaningful narrative. In order to draw out the distinctions between what I am calling the radical anonymity of the bit and the comforting commonplace of the generic whole, we can examine two other authors' roughly contemporary fictional representations of war. Both demonstrate how an individual can become anonymous through the stripping of identity, down to the nub. This is the rendering of a person into small bits before subsequently fusing them into a new whole. These works also show how the military was imagined and represented as capable of producing radical anonymity prior to the Second World War and the advent of the new media culture that, Paul Fussell argues, stripped "individual personality" from the newly "uniform and anonymous" military $(66-67){ }^{2}$

In a crucial scene from Stephen Crane's The Red Badge of Courage (1895) that appears prior to the first battle, Crane describes Henry Fleming, his young antihero, as undergoing a transformation that results in the loss of his individuality: "He became not a man but a member. $\mathrm{He}$ felt that something of which he was a part-a regiment, an army, a cause, or a country-was in crisis. He was welded into a common personality which was dominated by a single desire" (26). The language of machine technology, the process by which he was "welded" into another subjectivity, or what Crane calls a "common personality," that was not his alone but shared by all the other young men, gives us a figure for the extent to which Fleming has become anonymous. The crisis is understood as requiring Fleming's consent to be transformed from a part into a member of a new whole. ${ }^{3} \mathrm{~A}$ fantasy logic is at work in this passage: there is a split or rupture within a unit ("a regiment, an army, a cause, or a country") that is presented as breaking a former wholeness that requires the subject's assent to patch up. It is only through his choice to become a "member," an anonymous soldier, that The Red Badge's "youth" can finally become a man.

While Crane represents the war narrative as requiring the production of an anonymous group prior to entering battle, Mark Twain imagines the remainders of war-those killed in such a battle—as similarly 
anonymized. A Connecticut Yankee in King Arthur's Court (I 889) concludes in a horrific battle that because of the anachronistic introduction of late nineteenth-century firearms against the twelfth-century opponents results in a complete massacre. Twain's transported technologist of war, Hank Morgan, describes the scene: "As to the destruction of life, it was amazing. Moreover, it was beyond estimate. Of course we could not count the dead, because they did not exist as individuals but merely as homogenous protoplasm, with alloys of iron and buttons" (396). Torn to bits by these out-of-place bullets, the knight-soldiers are, like Henry Fleming and his peers, combined into a larger, anonymous unit. Twain's representation of this scene allies the technological to the mathematical sublime by rendering the dead uncountable in their individuality. Reduced to protoplasmic parts, and not even identifiably human parts but those produced by machines-the already deindividuated, amalgamated commodities of buttons and iron - the pile of former soldiers signifies anything but the generic. While the generic signifies a lack of individuating predicates that can still represent a type or category, the radically anonymous is essentially dispensable, a reproducible throwaway that derives value not from the ability to stand in for a larger whole but from adding, bodily as in Twain's protoplasm, to the whole.

Yet radical anonymity isn't the sole province of disfiguring war narratives. We find versions of the "precariousness of personal identity ... at the moment of its disintegration" that Sharon Cameron groups under the name "impersonality" in many works of American literature of the nineteenth century (viii). Think of Edgar Allan Poe's proto-cyborg general of "The Man That Was Used Up," who is composed and decomposed by anonymous publicly circulated discourse-gossip-and the oddly impersonal personage who haunts London's crowded urban locales in "The Man of the Crowd." These two stories enable us to draw connections between the anonymity associated with war and that of the crowd. The latter story exposes that even particularity might just be another marker of radical anonymity - the otherwise featureless "countenance of the singular being" belonging to that anonymous old stranger trailed by Poe's narrator (22I). This stranger is thus situated at precisely the junction of the personal and the impersonal. Poe, as always, helps to expose the perverseness of commonplace scenes and situations. As more people shift into urban living-the rapid expansion of cities in America did not really take off until after the war-realism becomes 
more about representing the flow of large numbers of people and the transformation of social types into anonymous and autonomous figures. 4

As this nineteenth-century realist tradition gives way to twentiethcentury modernism, we see a shift from the comforting generality to the masses of anonymous, rather than anomalous, figures in cities. Maurice Blanchot exposes the conditions of what might make this version of anonymity so horrifying to Bierce through his conception of what he, after Henri Lefebvre, terms "everyday experience." If we think of Howells's comforting generic life of the middle class as being structured and threatened by those uncanny, weird figures that he describes as not belonging to the space of the general, we begin to see how Bierce's firstperson authored texts constantly restage a transformation from a state of particularity to anonymous subjectivity. The space of anonymous subjectivity in Blanchot is the ongoing eventlessness of "day-to-day life" in the urban street. The term "everyday" carries with it a sense of repetition implicit in its name. One enters into the repetitive flow of the everyday, as one enters into the street, as a subject without qualities, a subject without predicates. It is, as Blanchot describes, human but at the same time it is a human space without particularity: "In the everyday we have no name, little personal reality, scarcely a face, just as we have no social determination to sustain or enclose us" ( I 7 ). 5 The crowds and the streets function to strip particularity from the subject and render it anonymous. If Howells happily represents himself or his characters as deindividualized individuals, it is because they belong to the genteel tradition of nineteenth-century realism of the everyday as centered in the generic, not the anonymous. The anonymous are those without particularity, those without faces. ${ }^{6}$

Against this mute anonymity, Bierce tries to introduce fragments that can once again individuate. Fragmented narratives, because they are not part of a whole or a cycle, might make it possible to avoid the repetitiveness associated with the anonymity of the everyday. The opening narrative bit of Bits of Autobiography, "On a Mountain," centers on one of the many small and uncounted events of the Civil War. He writes: "It has not got into history, but it had a real objective existence, although by a felicitous afterthought called by us who were defeated a 'reconnaissance in force"' (656). This autobiographical sketch, like all of Bierce's war stories, deflates any imagined heroism of war. He neither defends nor recalls any of his own actions. The event, as Bierce explains, lacks any 
representation, because it was deemed an utter failure and did not contribute to a progressive narrative capable of marching toward success.

But if the event remains uncounted, an even worse outcome is given to all the soldiers. Rather than tabulating a list of goals or missions accomplished and actions performed, Bierce describes the transformation of his fellow union soldiers into anonymous, faceless things: "As we trudged on we passed something-some things-lying by the wayside. During another wait we examined them, curiously lifting the blankets from their yellow-clay faces" (658-59). Bierce's depiction of an initially perceived unified "something" that, on closer inspection, separates into "some things" forms the first half of his attempt to make these men present. The second turns on a second transformation:

Repassing the spot the next day, a beaten, dispirited and exhausted force, feeble from fatigue and savage from defeat, some of us had life enough left, such as it was, to observe that these bodies had altered their position. They appeared also to have thrown off some of their clothing, which lay near by, in disorder. Their expression, too, had an added blankness-they had no faces. (659)

Ending with this image of a field filled with fellow, but unidentifiable, union soldiers, Bierce captures these now upturned and faceless bodies. Stripped of clothing and of any marking details, he describes them as completely lacking identity. The victims of a second attack, a herd of hungry pigs, these men who were nameless in history are made doubly so by Bierce's rendering them faceless.

The anomalous bit of detail in this narrative is the absence of the face as index of particularity, of individuality. A simple section marker, an asterisk, separates the before from the after of the event; formally, this division repeats the formula that structures the majority of Bierce's fictional tales in which a final "reveal" exposes formerly unexposed information that produces a doubling back that leads to a reinterpretation of the story. By deploying this formal device, by marking the final anonymity of these de-figured bodies as a supplement, Bierce's narrative insists on the "real objective existence" of this event and these men. His bit of complex narrative doesn't produce a more "accurate" history, but rather seeks to restore something missing from history through the 
inclusion of an element of unknowing, an unrecoverable knowledge of the event. This horrifying anonymity forces any reconstructed history to acknowledge its desire to exclude these moments of radical deindividualization in pursuit of writing the definitive account.

To render such a previously unrepresented event that he understands to have a "real objective existence" in the world of representation, Bierce needs to produce a shock that will disrupt the general story. To extract from memory these bits of individual experience and add them as a supplement to the official account is, for Bierce, to write a better history. Like "On a Mountain," the fragment titled "The Crime at Pickett's Mill" concerns these sorts of events:

There is a class of events which by their nature, and despite any intrinsic interest that they may possess, are foredoomed to oblivion. They are merged in the general story of those greater events of which they were a part, as the thunder of a billow breaking on a distant beach is unnoted in the continuous roar. $(684)$

Bierce avoids the writing of a "general story of those greater events" in favor of the condensed and compact story of what might be called the unnoted smaller events. Just as there are no representations of his childhood - or any experience prior to his transformation into an anonymous member of the Union Army-there are no moments of transcendence in which he takes stock of the entire event of the Civil War.

In his now somewhat neglected literary history of the I 89os, Larzer Ziff makes an interesting observation that connects Bierce's relation with everyday life to his fragmented war narratives: Bierce may have turned to his Civil War experience as a way of dealing with a certain repetitiveness of everyday life in fin-de-siècle America. While Howells might be said to have found comfort in the generalizing qualities of the everyday, Ziff presents us with a Bierce as disturbed by the tendency of everyday life to replicate the anonymity of the war experience. Adding this analysis suspends Bierce between two competing sets of stories that could be said to be going nowhere: "While his war-arrested mind led him to treat the day's news as mere repetitions of the same old story, at least that mind was constantly forced to face up to its repetitive task and so freed of the dangers of self-hypnosis that constantly threatened the imitators of Poe" ( I69). These experiences thus may have provided 
Bierce with the possibility of an almost eternal return of literary reserves, but they could not be integrated. Freed from many of the stagnant and stale topics of the day, Bierce must choose between the dull dailyness of the newly new "news" and his arrested bits of the suspended past. Thus, while these bits and shreds of narrative are indeed arresting, they remain fragmentary in their lack of integration.

It also becomes clear that the very thing that gives Bierce's narratives their singularity, their phenomenological specificity, draws them away from being components of a reflective whole "self"; instead they seem like random particles of sensory data. Bierce's perspective in these autobiographical fragments, and his work in general, is limited to his perceptual experience. There are few examples of even the presence of other people, never mind an understanding of how they are experiencing the time of the narrated events that they share with Bierce. And when other people do appear, any particularity of these other represented people tends to fall into generalizable — one might even say wellregimented-groups. Despite this tight focalization, his narratives are always about specific events. Perception, as Cathy Davidson argues, is Bierce's key technique. What she calls his "language of perception" can be seen in his frequent deployment of the image of a bodily response to external events in order to index an otherwise inaccessible interior state $(7-9)$. Bierce does so in an attempt to recover clarity of vision from past events, but this vision is always concerned with what was perceivable to a subject-to him-within the time of these events.

Unlike many traditional autobiographies, Bierce's bits of narrative frequently lack the intrusion of his authorial voice in favor of remaining within first-person awareness. This approach serves to delink the phenomenological experience of the event from a reflective whole self. Whereas Howells's autobiographies introduce and work to maintain a large gap between the author as an older man looking backward and his generalized boy-the "my boy" of his narrative-Bierce cannot escape that he was, and to some extent still is, the subject of his experience. This is no simple denial of his particular experience; he reconstructs his past to insist on himself as a reliable witness. He writes explicitly from his perspective and often draws attention to the degree to which he represents himself as an embedded subject. In "What I Saw of Shiloh," he positions himself thusly as a witnessing authority to the events related: 
In subordination to the design of this narrative, as defined by its title, the incidents related necessarily group themselves about my own personality as a center; and, as this center, during the few terrible hours of the engagement, maintained a variable constant relation to the open field already mentioned, it is important that the reader should bear in mind the topographical and tactical features of the local situation. (642)

His language of topography, which reflects his occupation as a topographer during the war, positions himself in relation to the events described while his method of recall requires him to reproduce the time of the event and the field of "variable constant relation." Using one's "personality as a center," however, leads not to the expected grounding of narrative but further fragmentation of that personality-this is the converse of that we saw earlier in Crane's representation of Henry Fleming as becoming-anonymous - and emerges from hypersubjective affective "bits" that fail to cohere into overarching meaning.

As Bierce's formal construction of his prose indicates, the time and experience of the event can only be reconstructed through the reassembly of his senses. In other words, he needs to recall a historical phenomenological experience through what might be thought of as the playback of a set of stored bodily sensations. We see an example of this device in the same "What I Saw of Shiloh" fragment:

And this was, $\mathrm{O}$ so long ago! How they come back to medimly and brokenly, but with what a magic spell— those years of youth when I was soldiering! Again I hear the far warble of blown bugles. Again I see the tall, blue smoke of the camp-fires ascending from the dim valleys of Wonderland. There steals upon my sense the ghost of an odor from pines that canopy the ambuscade. I feel upon my cheek the morning mist that shrouds the hostile camp unaware of its doom, and my blood stirs at the ringing rifle-shot of the solitary sentinel. (677)

These impressions come back as they were perhaps initially experienced, as a set of fragmentary, or broken, and disconnected sensory experiences that collectively locate the subject-as-witness to an event. Bierce indexes the event through what he recalls, in his ordering, as his senses of hearing, sight, smell, and feeling. These descriptive detailing 
fragments are, as I have argued, hypersubjective and they function, as Georg Lukács helpfully notes in his differentiation of narration from description, to bring about "a disintegration of the composition into disconnected and autonomous details" (132). The senses become, in Bierce's reconstruction of the past, autonomous and circulating, like the narrative incidents themselves; they group around the soldier as anonymous subject, not as a unit of particular meaning. The singular and punctual burst of the "rifle-shot of the solitary sentinel" pulls these fragmented senses together. But they do not cohere; instead they seem like random bits of sensory experience.

Any typical narrative from Bierce's short story oeuvre has an affectively charged transitional moment when the reader realizes that things are not what they appear to be. In his autobiographical work, we find moments that attempt to regain his state of consciousness during past traumatic events. His deployment of the same tropes that he understands to be capable of giving rise to an affective response suggests that he might imaginatively return to such scenes armed with his favorite formal devices in order to duplicate the intensity of first-person perception within an event. In his "The Short Story" essay, he lays out his argument for the primacy of the affects: "All the arts are essentially one, address the same sensibilities, quickening the same emotions and subject to the same law and limitations of human attention" (235). It is an affective response that Bierce desires, but the "personality" that is the addressee of these emotions cannot guarantee integration.

The small sensorial event of "What I Saw of Shiloh" contains the basic elements from his "Short Story" essay that lead to an affective "quickening" of the senses, yet it ends with a moment of traumatic closure, the closing to the "magic spell" constructed by his narrative. By concluding this scene with the bullet shot, Bierce displaces what would have produced the connective link in order to return him to his present scene of writing. He thereby abruptly cuts short his narrative with a figure of substitution rather than closure. The primal scene for this narrative punch is the moment of his wounding in June 1864 during the battle of Kennesaw Mountain. Bierce was shot in the head during the battle, and the resulting injury essentially put him out of commission for the remainder of the war. Within his autobiographical work, this traumatic event has been utterly displaced by scenes of substitution that function to repeat this moment of wounding, displacement that allows 
him to produce a doubling of this event. By deferring any representation of this scene itself, he holds this event open to representation. Believing that art is an address to the senses that should provoke the emotions, he also figures these scenes of repetition, in which he reenacts his displaced and unrepresentable traumatic wounding, as fundamentally caused by exposure to these same emotions. Thus the "absent cause" of this primal scene is continually re-presented and reawakened in the service of his art.

The one mention of his wounding, in all of his autobiographical accounts, appears in the fragment titled "Four Days in Dixie." This story also includes a representation of the repetition of the moment of wounding as caused by a set of specific symptoms, thus providing evidence for the theorization of what might be termed the "after affects" of Bierce's deindividuated sensorium. He contains the account of the wounding within a later period of lost consciousness that was produced by the sudden occurrence of these feelings. This passage thus displaces his first-person narration with a brief mention of this unnarrated event. In describing repetition of the wounding as caused by and in the terms of the same affects that he hopes to be produced by his aesthetic ideal as detailed in "The Short Story," Bierce makes his text into an affective mise-en-abîme.

At the battle of Kennesaw Mountain in the previous June I had been badly wounded in the head, and for three months was incapacitated for service. In truth, I had done no actual duty since, being then, as for many years afterward, subject to fits of fainting, sometimes without assignable immediate cause, but mostly when suffering from exposure, excitement or excessive fatigue. (689)

Bierce describes his response to such extreme events, triggered by "exposure, excitement or excessive fatigue," as if reenacting the moment of wounding. The "actual" event itself lacks representation, and the phenomenological experiences that are his signature literary style are displaced in this passage by the stasis of incapacitation. The wounding produces more than a loss consciousness; it strips him of his identity. To have "no actual duty" is to have a job without a description, to be a subject without a mandate. This state is akin to what I have described 
before as Bierce's representation of becoming anonymous-it is hypersubjective and an embodied consciousness without particularity.

Perhaps Bierce's discomfort with phenomenological specificity results from the fact that he is as anxious over the idea of a fixed identity as over the idea of anonymity. A glance at his fictional story "A Resumed Identity" (I908) suggests as much. This story opens with an unnamed, solitary man wandering around an almost barren hilltop attempting to figure out exactly where he is until he suddenly encounters another man, Dr. Stirling Malson, a country physician. The unnamed man immediately attempts to identify Dr. Malson as either a friend or foe, offering his own identity as a lieutenant on the staff of General Hazen. The man continues his line of inquiry, asking if Malson has heard any news about the battle. Malson dodges the questioning with his own; he asks whether the man has been injured. The lieutenant replies that he was grazed by a bullet to the head and has been unconscious for some time, but now, examining his fingers, he mysteriously can see no evidence of his injury, no blood. Malson attempts to treat the man gently with his questions but is dismissed as being unhelpful. Then, continuing to wander around the hill, the lieutenant comes across a monument to General Hazen's brigade and a commemorative note about the battle. In a moment of sudden realization, the lieutenant falls forward to his death in a pool of reflective water.

This story was most likely written after Bierce changed his mind about visiting former battlefields and about participating in commemoration and memorial activities. There is evidence that he had visited one such location, Stone River, also the site of this story. ${ }^{7}$ I want to resist simply reading this story through the lens of Bierce's biographydespite my calling attention to the similarity of the head wound suffered by this protagonist to Bierce's own injury-proposing instead that we consider it as a theory of his own autobiographical project. Autobiography, after all, is deeply concerned with creating the author's selfreflection and negotiating between the universal of understandable experience and the particularity of the author.

While Bierce's story seems to confirm that advice found in the second of the three section titles that divide the story-"When you have lost your life consult a physician" (300)—the ending complicates the placing of our trust in Dr. Malson and his amnesia cure. While 
debating how to respond to the lieutenant, Malson "[recalls] much that is recorded in the books of his profession-something about lost identity and the effect of familiar scenes in restoring it" (301). Rather than following this advice and allowing this confused man to locate his "lost identity" on his own, Malson begins to ask why the lieutenant is not dressed as such and expresses his disbelief at the man's reported age of twenty-three. Thus two versions of the cure are rejected: neither returning to the past nor awareness of the radical disjuncture between past and present seems capable of restoring one's former identity and enabling one to move forward.

The target of any such cure, of course, is not exactly the amnesia of the past experienced by this soldier, but of the present and all that has happened since a single, particularizing point in history. Thus Bierce must also issue a caution against the dangers of the autobiographical project by alerting the reader-as he puts it in the title of the final sectionto "the danger of looking into a pool of water" (302). It tells us that to have a single, frozen identity is worse than remaining anonymous. Writing autobiography, for Bierce, means risking a form of self-fixation, itself a form of defacement. ${ }^{8}$ To fix or complete a narrative, an event, or even an idea of the self is to produce closure. In other words, it would involve a commitment to what Friedrich Nietzsche calls monumental history, a mode—or, to use his term, "species"—of history in which the past exists in a fixed and unbroken relation to the present. ${ }^{9}$ The subject who frustrates this project does so out of a need for an open-ended, future-oriented narrative as well as a reworkable past—one that is not trapped, like one of Bierce's walking dead, within the confines of a now-impersonal singular identity. The de-completer of autobiographical narrative, then, does not yearn for a return of a lost wholeness, but rather holds to the problematic tensions between the bit and the totality.

Bierce views himself partially through the identity he gained when a soldier in his twenty-third year of life. That Bierce deploys the term "bit" to describe the smallest part of his autobiographical writing should be recognized as his own admission of the partial nature of these works. These short narratives do not function exactly like synecdoche for the longer and unwritten life. Rather, these are key moments within his life narrative that share aspects with other narratives, and though incomplete they do not suggest that a "full" version of his autobiography could ever be written.

Dartmouth College 


\section{NOTES}

I wish to express thanks to Jennifer L. Fleissner for numerous contributions to this essay and for sharing her syllabus for her "The Everyday" seminar with me. Thank you also to Jonathan Elmer for introducing me to Ambrose Bierce, to Donald E. Pease for his incisive and generous criticism, and finally to Louis A. Renza for his careful reading of this essay and for his continued sharpening of my understanding of autobiography.

I. This works according to the logic of what Barthes calls the "reality effect." In several of his third-person authored autobiographies including A Boy's Town ( I 890), Howells uses "bits" of the experience from a "specialized boy" to authorize the writing of what he terms his "boy in general," his common story. The fiction of the generic boy is comforting to Howells but it requires the supplement of the specialized boy to make it the common story. We find a similar operation of what we can think of as the real of Howellsian realism in his fiction. The opening scene of Indian Summer features a busy Florence street scene and an anomalous figure with one leg, who is briefly mentioned and then quickly pushed from view, a trope Howells uses to establish the reality of his representation of this scene of everyday life.

2. Fussell examines representations of what he terms the "faceless young automatons" $\left(6_{7}\right)$ as linked to growth of the mass media and the new methods of propaganda distributed by warring governments via these new media.

3. Warner's understanding of the self-alienation required by what he terms "mass-public subjectivity" might also be a useful lens by which to examine the assent required to become an anonymous subject. He writes: "If mass-public subjectivity has a kind of singularity, an undifferentiated extension to indefinite numbers of individuals, those individuals who make up the 'we' of the mass-public subject might have very different relations to it. It is at the very moment of recognizing ourselves as the mass subject, for example, that we also recognize ourselves as minority subjects. As participants in the mass subject, we are the 'we' that can describe our particular affiliations of class, gender, sexual orientation, race, or subculture only as 'they.' This self-alienation is common to all of the contexts of publicity, but it can be variously interpreted within each" ( I 7 I ).

4. See Simmel's sociological analysis of the exchange of money as promoting anonymity in the urban market in his 1903 essay "The Metropolis and Mental Life" $(324-38)$.

5. Blanchot's conception of the everyday describes something that seems more like a modernist sense of everyday life by which meaning might be produced from the meaningless. Those dull, empty representations or, to put it in Blanchot's terms, "nul moments," in nineteenth-century realism are full of signification-they are not aestheticized insignificance. See also Olson.

6. In a sense this understanding of the everyday is opposed to de Certeau's heroic "common man," who lacks specificity but seems more like Howells's generic boy than the more insidious figure that I wish to extract from Blanchot. 
7. For a biographical reading of this story and details on Bierce's travels in his final years, see Talley.

8. I use the term "defacement" here in order to gesture toward de Man's wellknown account of autobiography as less a form of disclosure than of dis-enclosure: "The interest of autobiography, then, is not that it reveals reliable self-knowledgeit does not-but that it demonstrates in a striking way the impossibility of closure and of totalization (that is the impossibility of coming into being) of all textual systems made up of tropological substitutions" (922).

9. Nietzsche critiques the monumental mode of history that seeks to frame the past as a chain of continuity that stretches across human history (69). Bierce's "bits" can be thought of as links broken off from the chain of the monumental autobiography.

\section{WORKS CITED}

Barthes, Roland. "The Reality Effect." The Rustle of Language. Trans. Richard Howard. New York: Hill, I986. I4I-49. Print.

Bierce, Ambrose. Ambrose Bierce: The Devil's Dictionary, Tales, and Memoirs. Ed. S.

T. Joshi. New York: Library of America, 20 I r. Print.

. "The Crime at Pickett's Mill." i909. Ambrose Bierce 684-92.

. "Four Days in Dixie." I 909. Ambrose Bierce 693-70 I.

"A Resumed Identity." I908. Ambrose Bierce 298-303.

"The Short Story." I 897. The Collected Works of Ambrose Bierce. Vol. Iо. New York: Neale, I 9 I . 234-49. Print.

. A Sole Survivor: Bits of Autobiography. Ed. S. T. Joshi and David E. Schultz. Knoxville: U of Tennessee P, I998. Print.

. "What I Saw of Shiloh." i 909. Ambrose Bierce 66o-78.

Blanchot, Maurice. "Everyday Speech." Trans. Susan Hanson. Yale French Studies 73 (1987): 12-20. Print.

Cameron, Sharon. Impersonality: Seven Essays. Chicago: U of Chicago P, 2007. Print.

Crane, Stephen. The Red Badge of Courage. I 895. New York: Norton, I 999. Print.

Davidson, Cathy N. The Experimental Fictions of Ambrose Bierce: Structuring the Ineffable. Lincoln: U of Nebraska P, i 984 . Print.

De Certeau, Michel. The Practice of Everyday Life. Trans. Steven F. Rendall. Berkeley: $U$ of California P, 1984. Print.

De Man, Paul. "Autobiography as De-facement." MLN 94.5 (r979): 919-30. Print.

Fussell, Paul. Wartime: Understanding Behavior in the Second World War. New York: Oxford UP, 1989. Print.

Howells, William Dean. A Boy's Town. New York: Harpers, i89o. Print. 
Lukács, Georg. "Narrate or Describe?" Writer and Critic: and Other Essays. Ed. and trans. Arthur Kahn. New York: Grosset, I970. I Io-I 48. Print.

Nietzsche, Friedrich. "On the Uses and Disadvantages of History for Life." [first trans.] i 983. Untimely Meditations. Ed. Daniel Breazeale. Trans. R. J. Hollingdale. New York: Cambridge UP, I 997. 57-124. Print.

Olson, Liesl. Modernism and the Ordinary. New York: Oxford UP, 2009. Print.

Poe, Edgar Allan. Complete Stories and Poems of Edgar Allan Poe. Garden City: Doubleday, i966. Print.

—. "The Man of the Crowd." I 840. Complete Stories and Poems 2 I 5-2 I.

. "The Man That Was Used Up." I 850. Complete Stories and Poems 350-57.

Simmel, Georg. "The Metropolis and Mental Life." i 903. On Individuality and Social Forms. Trans. and ed. Donald N. Levine. Chicago: U of Chicago P, I97 I. 32439. Print.

Talley, Sharon. Ambrose Bierce and the Dance of Death. Knoxville: U of Tennessee P, 2009. Print.

Twain, Mark. A Connecticut Yankee in King Arthur's Court. I889. New York: Penguin, I97 I. Print.

Warner, Michael. Publics and Counterpublics. New York: Zone, 2005. Print.

Ziff, Larzer. The American I89os: Life and Times of a Lost Generation. New York: Viking, I966. Print. 